\title{
PENINGKATAN KESEJAHTERAAN MASYARAKAT MELALUI PENINGKATAN NILAI PRODUK DI KABUPATEN SUBANG
}

\author{
Ferdi Fathurohman ${ }^{*}$, Rita Purwasih ${ }^{2}$, Ridwan Baharta ${ }^{3}$, Wiwik Endah Rahayu ${ }^{4}$, \\ Nurul Mukminah ${ }^{5}$, Enceng Sobari ${ }^{6}$, Irna Dwi Destiana ${ }^{7}$ \\ 1,2,4,5,6,7 Jurusan Agroindustri, Politeknik Negeri Subang. \\ Jl. Arief Rahman Hakim No. 08 (Islmaic Center) Cigadung-Subang 41213 \\ ${ }^{3}$ Jurusan Teknologi Pertanian, Politeknik Negeri Lampung, Lampung \\ Jl. Soekarno-Hatta No.10 Bandar Lampung-Lampung \\ Penulis Korespodensi : ferdifathurohman@polsub.ac.id
}

\begin{abstract}
Abstrak
Kabuapten Subang merupakan sentra penghasil buah nanas terbesar di Indonesia. 500 keluarga menggantungkan penghasilannya dari bertani nanas, dengan kepemilikan lahan perkebunan rata-rata 0,4 Ha, namun petani hanya terfokus kepada produksi nenas belum menyentuh kepada pengolahan hasil.sehingga yingkat kesejahteraan petani masih belum optimal. Pengabdian masyarakat ini bertujuan menambah pengetahuan petani melalui penyuluhan dan pembinaan mengenai tata cara pegolahan produk nanas seupaya memiliki nilai tambah. Pelaksanaan pengabdian kepada masyarakat dilaksanakan di Kecamatan Compreng, Kabupaten Subang selama bulan Juli sampai Oktober 2019 dengan menggunakan metode ceramah, focus group discussion, pelatihan dan pendampingan serta monev. Hasil dari pengabdian masyarakat ini yaitu masyarakat dapat membuat olahan dari nanas sebagai upaya dalam meningkatkan nilai tambah dari produk nanas itu sendiri. Kesimpulan dari pengabdian masyarakat ini yaitu pelaksanan kegiatan pengabdian masyarakat maтри membantu masyarakat untuk meningkatkan kesejahteraan melalui peningkatan nilai produk dan nilai jual dari produk serta masyarakat mampu mengembangkan manajemen kelembagaan.
\end{abstract}

Kata kunci: peningkatan kesejahteraan nilai tambah, nanas, subang

\section{Pendahuluan}

Pembangunan masyarakat adalah rangkaian kegiatan yang berkesinambungan dan merupakan upaya untuk mengembangkan kemampuan masyarakat agar mampu melaksanakan usaha yang produktif dibidangnya secara mandiri. Pembangunan masyarakat khususnya masyarakat pertanian tersebut dilakukan dari hulu ke hilir. Menurut (Fathurohman, 2018a) di masa mendatang, pembangunan masyarakat memiliki visi yaitu mewujudkan masyarakat yang maju, efisien, dan tangguh, kompetitif, mandiri dan berkelanjutan serta mampu memberdayakan ekonomi rakyat.

Kabupaten subang memiliki jumlah penduduk 1.546.00 jiwa yang terbagi menjadi tiga karakteristik wilayah yaitu pegunungan, dataran rendah dan pantai (Dinas Peternakan dan Kesehatan Hewan Kabupaten Subang, 2016). Kementerian Pertanian telah menetapkan Jawa Barat khususnya Kabupaten Subang menjadi salah satu kabupaten di Jawa Barat sebagai Kawasan
Komoditas pertanian buah nanas yang juga merupakan merupakan kawasan percontohan yang dirancang sebagai pengujian dalam rangka menunjukan keefektifan suatu pelaksanaan program, mengetahui dampak pelaksanaan program dan keekonomisannya. Kabupaten Subang dipilih sebagai kawasan komoditas pertanian buah nanas karena memiliki sumber daya alam serta sarana dan prasarana yang pendukung pengembangan buah nanas. Kabupaten Subang diharapkan mampu menjadi salah satu kawasan pertanian komoditas nanas di Indonesia yang dapat berkontribusi dalam penyediaan buah nasional nasional. (Fathurohman, 2018b)

Berkaitan dengan hal diatas, pemerintah kabupaten Subang memfokuskan pengembangan buah nanas ini kepada sektor-sektro yang memiliki nilai tambah yang tinggi. Diharapkan dengan memiliki nilai tambah yang tinggi dapat mewujudkan petani nanas yang berdaulat dan mandiri. Salah satu kelompok atau binaan yang dijadikan rintisan yaitu terletak di Desa Sukadana, 
Kecamatan Compreng, Kabupateng Subang, Jawa Barat. Di desa ini menaungi 3 kelompok pengolah yang terdiri lebih dari 50 anggota masyarakat. (Politeknik Negeri Subang, 2015)

Salah satu faktor terpenting dalam usaha pertanian yaitu bahan baku dan pengolahan hasil pertanian. Namun demikian, masih banyak masyarakat yang menjual langsung buah nanas tanpa melakukan pengolahan. sehingga nilai tambah dari buah nanas itu sendiri menjadi kurang optimal. Banyak petani nanas yang mengalami kerugian akibat biaya produksi lebih tinggi dibandingkan dengan harga jual buah nanas. Hal ini kurang pahamnya petani akan pengolahan nanas dan kurangnya kelembagaan dalam masyarakat itu sendiri, hal tersebut dikarenakan $70 \%$ dari rantai harga buah nanas dipengaruhi oleh faktor diluar petani dan $30 \%$ saja faktor dari petani, artinya harga dikuasai oleh pedagang bukan oleh petani. (Mahaputra \& Kurniadhi, 2003).

Secara umum usaha pertanian khususnya buah nanas memiliki beberapa resiko yang sering dihadapi yaitu harga, pengolahan, daya simpan, pergudangan, pemasaran, dan rantai perdagangan, resiko ini berbeda-beda tergantung dari wilayah sentra produksinya (Fathurohman, Sobari, \& Mukminah, 2017). Berdasarkan pemaparan diatas dan survey yang dilakukan di Kabupaten Subang beberapa masalah yaitu terkait (Fathurohman, 2018a):

1. Pengolahan yang sangat minim

2. Daya simpan yang relatif sebentar

3. Belum efektifnya manajemen pengelolaan kelompok

Pengabdian masyarakat ini dimaksudkan sebagai upaya mengatasi permasalahan diatas dan menambah pengetahuan masyarakat khususnya keluarga petani melalui penyuluhan, pelatihan dan pembinaan mengenai tata cara pembuatan pengolahan produk dengan memanfaatkan peralatan yang sederhana dan dengan biaya yang rendah. (Vernanda \& Abdullah, 2018)

Target yang hendak dicapai dari kegiatan pengabdian masyarakat ini adalah meningkatkan pengetahuan dan keterampilan masyarakat akan pengembangan pembangunan produk pertanian khususnya nanas melalui peningkatan nilai tambah dan nilai jual serta perbaikan manajemen pengelolaan kelompok yang lebih efisien (Susandy \& Prasetyo, 2016). Luaran kegiatan pengabdian masyarakat ini adalah publikasi ilmiah.

\section{Metode Pelaksanaan}

Kegiatan pengabdian masyarakat dilakukan di S Desa Sukadana, Kecamatan Compreng, Kabupateng Subang selama bulan Juli sampai dengan Oktober 2019. Apapun metode yang digunakan dalam pelaksanaan kegiatan pengabdian kepada masyarakat ini dilakukan dalam tiga tahap yaitu:

1. Tahap Focus Group Discussion (FGD) dan tahap penyuluhan dilakukan dengan metode ceramah, dan diskusi terkait permasalahan masyarakat dan manajemen pengelolaan kelompok.

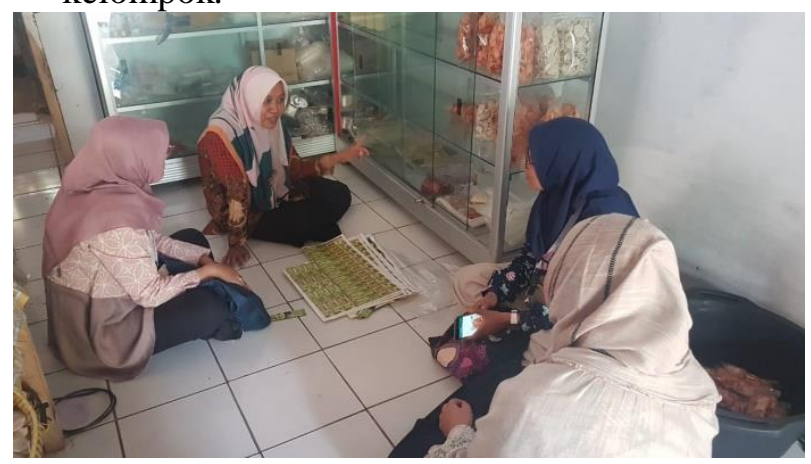

Gambar 1. FGD dan Penyuluhan

2. Tahap pelatihan dan pendampingan, dilakukan dengan metode pelatihan langsung dengan praktek, yiatu dengan membuat selai nanas dan dodol nanas dengan bahan baku nanas yang kualitas jelek atau tidak layak jual. selain itu dilakukan pendampingan pembentukan manajemen kelompok.

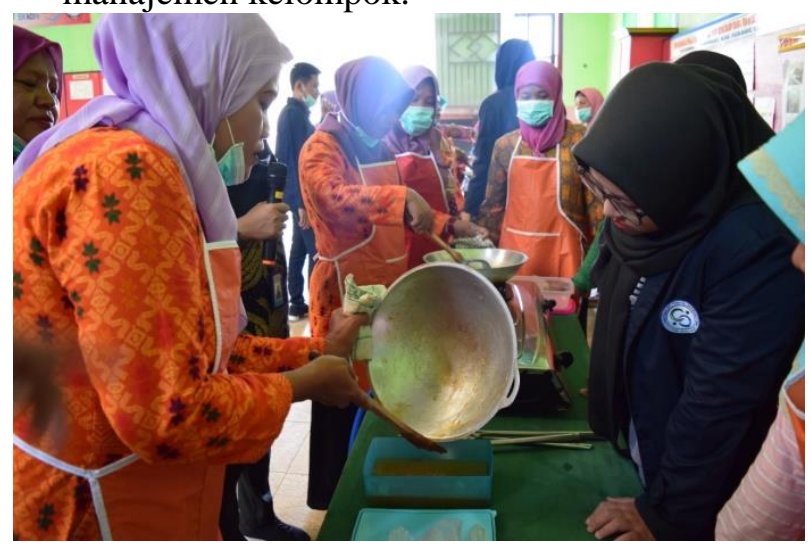

Gambar 2. Pelatihan pembuatan selai dan dodol nanas

3. Tahap monitoring dan evaluasi (monev), dilakukan dengan pencatatatan produktivitas pembuatan olahan nanas dan peningkatan penghasilan serta memantau perkembangan dari keterampilan pembuatan produk olahan yang telah diberikan, monev juga dilakukan terhadap 
manajemen kelompok di setiap kelompok guna penyeragaman.

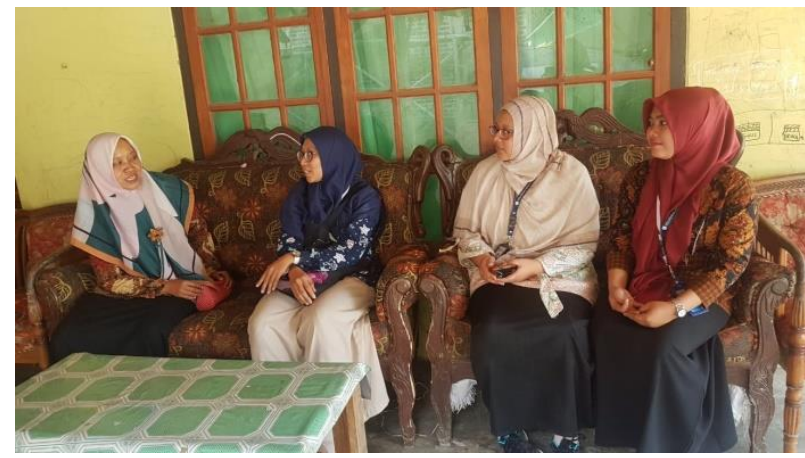

Gambar 3. Tahap Monev

\section{Hasil yang Dicapai}

Pelaksanaan pengabdian masyarakat telah dilaksanakan di Kecamatan Compreng, Kabupaten Subang selama bulan Juli sampai dengan bulan Oktober 2019. Kegiatan ini melalui 3 tahap yaitu tahap FGD dan penyuluhan, pelatihan dan pendampingan, serta monitoring dan evaluasi.

Kegiatan pengabdian masyarakat di Kecamatan Compreng memiliki indikator yang diketahui dari peningkatan penghasilan dan kualitas dari produk dan kemampuan masyarakat dalam membuat olahan produk serta perbaikan manajemen kelompok. Target dari kegiatan pengabdian masyarakat ini adalah meningkatkan pengetahuan dan keterampilan akan pengolahan produk sehingga dapat meningkatkan nilai jual dan tentunya meningkatkan penghasilan dan kesejahteraan masyarakat, selain itu adanya penyamaan manajemen kelompok di setiap kelompok masyarakat.

Adapun hasil yang dicapai dalam setiap tahapan pengabdian masyarakat yaitu :

1. Tahap FGD dan penyuluhan, terdatanya permasalahan yang ada di setiap kelompok masyarakat, meningkatkan pengetahuan masyarakat akan nanas dan produk olahannya, utamanya adalah tentang peningkatan nilai produk sebagai upaya pengembangan peningkatan kesejahteraan masyarakat. masyarakat mengerti dan paham tentang manajemen kelompok yang efisien dan efisien.

2. Tahap pelatihan dan pendampingan, meningkatkan pengetahuan dan keterampilan para masyarakat dalam membuat olahan nanas dengan bahan baku nanas kualitasnya jelek atau tidak layak untuk dijual. Tahap pelatihan diakhiri dengan perbaikan kemasan dan pemberian label.

3. Tahap monev, dilaksanakan oleh tim pelaksana pengabdian masyarakat dan Pusat Penelitian dan Pengabdian Kepada Masyarakat (P3M) Politeknik Negeri Subang. Oleh tim pelaksana, hasil monev didapat kualitas produk dan keterampilan pembuatan produk dalam hal ini selai dan dodol nanas meningkat selain itu adanya keseragaman manajemen kelompok yang lebih efisien dan efektif dibandingkan dengan sebelumnya. Hasil monev menunjukan bahwa terdapat kesesuaian antara proposal yang diajukan dengan keadaan dilapangan.

Meskipun demikian, secara teknis terdapat beberapa kendala yang ditemukan selama rangkaian pelaksanaan pengabdian masyarakat dan sekiranya akan menjadi evaluasi dan perbaikan untuk kegiatan pengabdian masyarakat dimasa mendatang. Kendala-kendala tersebut yaitu :

1. Perubahan jadwal yang sebelumnya telah disepakati oleh Tim Pelaksana dan masyarakat sehingga mengakibatkan terjadi penundaan dan penggabungan kegiatan yang sebelumnya telah direncanakan.

2. Kurangnya antusiasme masyarakat untuk mengikuti rangkaian acara pengabdian masyarakat, sehingga materi yang disampaikan tidak merata.

\section{Kesimpulan}

Pelaksanan kegiatan pengabdian masyarakat mampu membantu masyarakat untuk mengembangkan produk olahan melalui peningkatan pengetahuan dan keterampilan pembuatan dengan memanfaatkan bahan baku yang kualitasnya jelek dan tidak layak untuk dijual sehingga dapat menekan biaya produksi khususnya biaya bahan baku, dapat membentuk manajemen pengelolaan yang lebih efektif dan efisien, selain itu penghasilan masyarakat lebih meningkat dibandingkan dengan sebelumnya.

\section{Ucapan Terima Kasih}

Ucapan terima kasih penulis tujukan ditujukan kepada Pusat Penelitian dan Pengabdian kepada Masyarakat Politeknik Negeri Subang yang telah 
memberikan pendanaan untuk pengabdian kepada masyarakat ini. Ucapan terima kasih juga penulis sampaikan kepada Masyarakat Kecamatan Compreng, Dinas Pertanian Kabupaten Subang dan Dinas Koperasi dan UMKM Kabuaten Subang.

\section{Daftar Pustaka}

Dinas Peternakan dan Kesehatan Hewan Kabupaten Subang. Pilot Project Kawasan Peternakan Sapi Potong Kabupaten Subang (2016).

Fathurohman, F. (2018a). Business Model of Subang District Ranch Area. Jurnal Ilmiah Ilmu dan Teknologi Rekayasa, 1(1), 36-45. https://doi.org/10.17605/OSF.IO/MA3BG

Fathurohman, F. (2018b). EKONOMI TEKNIK PERTANIAN (1 ed.). Subang: POLSUB PRESS.

Fathurohman, F., Sobari, E., \& Mukminah, N. (2017). Human Resources Development Strategy In Brucellosis Diseases Monitoring at Sentra
Peternakan Rakyat Cinagarabogo, Subang. In Advances in Health Sciences Research (AHSR), volume 5 1st International Conference in One Health (ICOH 2017) (hal. 169-173). Malang: Atlantis Press. https://doi.org/10.2991/icoh17.2018.33

Mahaputra, S., \& Kurniadhi, P. (2003). Analisis Biaya Pemeliharaan Domba Dengan Complete Feed. Buletin Teknik Pertanian, 8(2), 47-48.

Politeknik Negeri Subang. (2015). Rencana Strategi dan Rencana Oprasional Politeknik Negeri Subang 2015 - 2019. Subang: Politeknik Negeri Subang.

Susandy, G., \& Prasetyo, Y. E. (2016). Analisis Pusat Pertumbuhan Subang. Dimensia , 13(2), 93-116.

Vernanda, D., \& Abdullah, A. (2018). Internet Literacy of Vocational High School Teachers. IOP Conference Series: Materials Science and Engineering, 306(1), 28-32. 